\title{
AN EMPIRICAL STUDY OF THE FACTORS AFFECTING THE ADOPTION OF MOBILE ENTERPRISE APPLICATIONS
}

\author{
J. van den Berg ${ }^{1} \& \mathrm{E}$. van der Lingen ${ }^{1 *}$
}

\section{ARTICLE INFO}

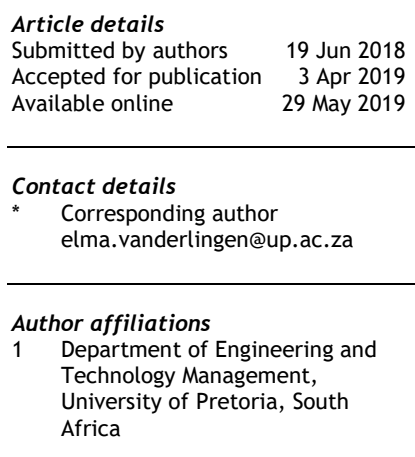

DOI

http://dx.doi.org/10.7166/30-1-1992

\begin{abstract}
Mobile enterprise application (MEA) technology has been identified as a technology that could help organisations to improve productivity, reduce cost, and gain and sustain competitive advantages through enterprise-wide technology implementations. Despite its many potential benefits, the adoption of MEA has not been as extensive globally as anticipated. Research results indicate that perceived technology usefulness, ease of use, perceived competitive pressure, industry trends, information technology (IT) infrastructure, organisational policies processes and systems, employee knowledge and readiness, and organisational resources are important factors that shape the adoption intent of organisations towards MEA technology. Implications for practice and research are also discussed.
\end{abstract}

\section{OPSOMMING}

Mobiele besigheidstoepassingstegnologie (MBTT) is geïdentifiseer as 'n tegnologie wat organisasies kan help om produktiwiteit te verbeter, koste te verminder, en mededingende voordele te verkry en te onderhou deur middel van omvattende implementering van die onderneming. Ten spyte van vele voordele, is die aanvaarding van MBTT nie so omvangryk wêreldwyd as wat verwag is nie. Navorsingsresultate dui daarop dat waargeneemde tegnologie bruikbaarheid, gemak van gebruik, waargeneemde mededingende druk, bedryfstendense, IT-infrastruktuur, organisatoriese beleidsprosesse en -stelsels, werknemerskennis en gereedheid, sowel as organisatoriese hulpbronne is belangrike faktore wat die aannemings-voorneme van organisasies vir MBTT vorm. Implikasies vir praktyk en navorsing word ook bespreek.

\section{INTRODUCTION}

Mobile enterprise applications (MEA) have the potential to enhance organisational productivity significantly, and can also lead to radically re-engineered business processes that support a competitive strategy [1].

The adoption of MEAs has, however, not been as extensive as originally anticipated for most countries [2]. According to Basole [3], this phenomenon can, in most cases, be explained as a result of the following: (i) technology limitations in both software and hardware; (ii) security concerns over access and data storage; (iii) significant capital expense requirements to implement mobile information and communication technologies (mICT); (iv) complexity in maintaining multiple technology platforms and operating systems; and (v) technology reliability and maturity concerns. Despite these limitations, organisations are still cognisant of the potential that mobile enterprise application technologies hold to create core competencies, and the potential to create competitive advantages that could lead to new markets being unlocked $[4,5]$.

Murray [6] mentions various popular media publications that have reported on the exceptionally high expected growth rates for mobile business applications in the near future. This recent turnaround 
in the attitude towards the adoption of mobile enterprise applications can be attributed to the following technology trends:

- $\quad$ The emergence of standardised application platforms such as iOS, Android, and Symbian [7].

- Advances in computing power, display resolution, and peripheral equipment interfaces that allow seamless interaction [7].

- Improved wireless connective infrastructure with the introduction of 3G (EVDO/HSPA) and 4G (LTE/WiMax) networks [7].

- $\quad$ The emergence of mobile enterprise application platforms (MEAP) that allow for improved mobile application management (MAM) [8].

- $\quad$ The continuous trend in the reduction of data charges [9].

- The growing penetration of smart devices into consumer markets, allowing businesses the opportunity to expand their channel offerings [10].

Enterprise mobility is fast becoming one of the pillars of an organisational ICT strategy that is crucial to ensuring the drive towards business innovation [7]. The rapid pace of the adoption and advancement of smartphone and tablet technology creates opportunities for new and innovative information system solutions. This rapid consumer-driven adoption of devices should inevitably lead to an increase in the use of these devices for business purposes; and as this business need grows, so too will the need for content-rich mobile applications and services.

Murray [6] reports that, while the growth rates for MEAs are encouraging, many organisations in the process of implementing a mobile enterprise application strategy are struggling with low adoption rates. It has also been reported that the body of knowledge on factors affecting mobile business application adoption favours the business-to-consumer (B2C) channel, and that the business-toemployee (B2E) and business-to-business (B2B) channels have remained relatively unexplored $[1,11,12,13]$. Moreover, it has been reported that studies on factors affecting IT adoption have focused on individual-orientated information technologies, as opposed to more sophisticated organisational technologies [14]. Little work has been done on the factors that affect IT and MEA technology adoption at firm level [11]. Most studies have focused on individual technology-adoption factors and broad-based mobile internet technologies that were not specifically developed for smart devices such as mobile applications [11, 12, 13].

With more and more organisations realising the potential that MEA can offer, and even more mICT technologies moving to smart device platforms, the need for improved theoretical constructs that can be used to define effective long-term mobile strategies has been identified. This article adds to the existing technology-adoption theory, and provides organisations with greater insight into the factors that inform the decision to adopt MEA technology. It also provides organisations that are developing MEA technology with greater insight into the challenges that organisations face when adopting MEA technology, which in turn should allow them to redefine their value propositions in order to deliver a product that adds greater value.

This article explores the factors that affect IT adoption for South African organisations through the development and application of a technology-adoption model specifically developed for firm-level studies.

\section{LITERATURE}

Technology adoption is a theoretical extension of the early works of Rogers [15] on innovation diffusion theory (IDT), which was popularised in his book Diffusion of innovations. This theory was generalised by Rogers to describe how, why, and at what rates technologies spread through different cultures. Technology adoption is often illustrated in a lifecycle model that describes the acceptance of a new technology according to a set of demographic, psychological, and sociological characteristics of a user group. The adoption process exhibits a normal distribution when plotted over time, and illustrates the five categories of adopters: innovators, early adopters, early majority, late majority, and laggards (see Figure 1). 


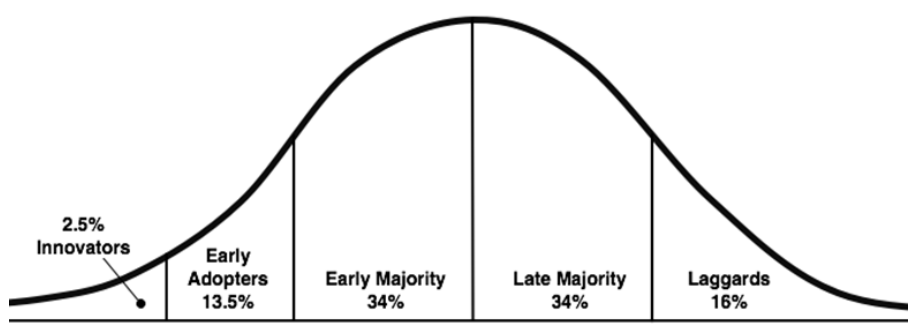

Figure 1: Rogers' innovation diffusion curve [15]

Research on technology adoption is one of the most mature streams in information systems research [16]. Various information technology-adoption theories have been introduced over the last three decades. Appendix 1 summarises the most popular individual and firm-level theories of technology adoption in information systems research. The following models have been identified as the most popular acceptance models that have been studied across various technologies and cultures: Technology acceptance model (TAM), Technology organisation environment (TOE), Innovation diffusion theory (IDT), Fit-viability model (FVM), and Unified theory of acceptance and use of technology (UTAUT). These are discussed below.

\subsection{Technology acceptance model (TAM)}

Davis [17] proposed a conceptual model for technology acceptance. In this model, he proposed that actual system use would be influenced by a user's motivation to use the system that, in turn, could be explained by systems features and capabilities referred to as 'external stimulus'.

From 1986 to 1996 the conceptual TAM model evolved through various stages, until the final TAM version was published by Davis and Venkatesh [18]. In this model, external variables were considered influential in an individual's beliefs about the perceived usefulness and perceived ease of use of a system.

The evolution of TAM to TAM 2 introduced subjective norms as an influential variable on perceived usefulness and intention to use. Other antecedents to perceived usefulness were also introduced to expand on the external variables that impact perceived usefulness: job relevance, image, output quality, and results demonstrability. TAM 3 included external variables for the antecedents that influence the perceived ease of use variable. The antecedents were divided into two main groups: anchors and adjustments.

Although TAM was originally developed to study individual level technology adoption, the application of TAM at a firm level is not entirely novel. The literature on business-level technology is scarce, however, compared with the literature examining technology adoption at an individual level. Yu and Tao [19] adopted TAM for a business-level technology-adoption implementation. The model defined in their study is illustrated in Figure 2.

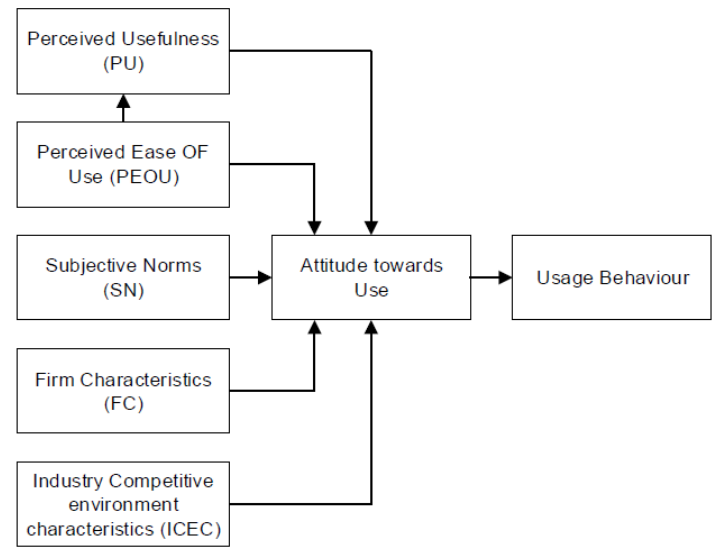

Figure 2: Business-level TAM [19] 


\subsection{Innovation diffusion theory (IDT)}

Innovation diffusion theory (IDT), also known as 'diffusion of innovation' (DOI), was introduced to explain the adoption rate for various technologies across various channels and stages [15]. The theory surmised that individuals have varying degrees of enthusiasm to adopt innovation, and that over time, or depending on which stage in the adoption process the adopter found themselves, the decision-making characteristics would change. From this model it can been seen that the characteristics of the adopter act as moderators that can either support or weaken the perception of an innovation's characteristics.

The literature on studies of technology adoption at enterprise level using IDT is copious. A literature review conducted by Oliveira and Martins [20] cited IDT studies on various technologies, such as: material requirements planning systems, enterprise planning systems, intranet and websites, and ebusiness technologies. Yu and Tao [19], however, reported that studies directly related to firm-level adoption remain relatively scarce.

IDT's robustness in explaining technology acceptance has been widely publicised, with reference to IDT, in thousands of articles across various disciplines, technologies, and cultures. Some issues have, however, been highlighted in using this adoption model: (i) no unified model exists [21], and (ii) it is an over-simplified theoretical model [22, 23].

\subsection{Technology-organisation-environment (TOE) framework}

The technology-organisation-environment (TOE) framework is an organisational-level theory developed by Tornatzky and Fleischer [24] to elucidate the elements that influence the technologyadoption decision within a firm context. The framework broadly identified three elements that influence the adoption process at firm level: the technological organisational, and environmental contexts. Figure 3 is an illustration of the TOE framework.

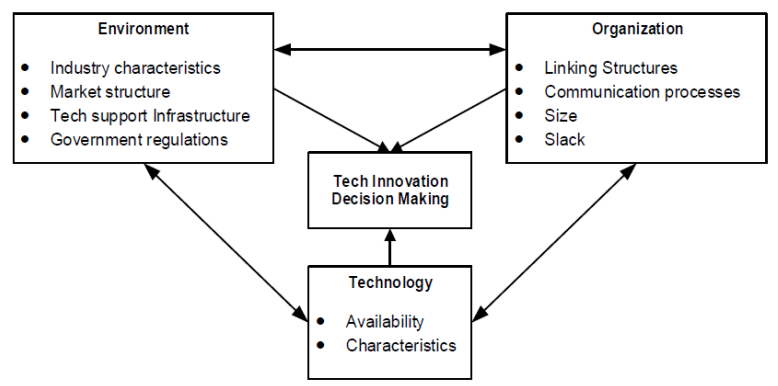

Figure 3: TOE framework [24]

The TOE framework has provided useful guidance for researchers and practitioners in the information systems technology-adoption space. The major limiting factor of this framework is the variety of competing models that exist alongside TOE. Baker [25] suggests that the ideas from within the major competing theories should be refined and included in the TOE, to ensure that the model remains parsimonious and broadly applicable.

\subsection{Fit-viability model (FVM)}

Tjan [26] proposed the use of a two-dimensional matrix for firms to assess their technology-adoption strategy. This decision matrix would then suggest whether the technology should be discarded, accepted but with organisational restructuring, investigated for alternatives, or accepted unequivocally. One dimension of the model was defined as fit, and the other was viability. Liang et al. [27] adapted the original fit-viability model by combining the theory of task-technology fit with the notion of the organisational impact of IT.

The 'fit' dimension stems from the theoretical work done by Goodhue and Thompson [28] on tasktechnology fit (TTF), which asserted that a greater fit between technology characteristics, task requirements, and individual abilities will ensure improved performance. The FVM adaptation moves the individual considerations to the viability dimension to ensure that a more objective assessment can be obtained for the match between task and technology. Figure 4 illustrates the adaptation of the FVM from Liang et al. [27]. 


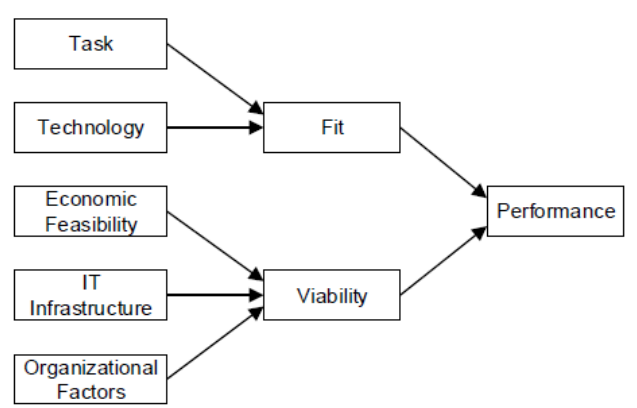

Figure 4: FVM framework for information systems (IS) [27]

'Viability' refers to an organisation's readiness for the technology. Three factors that influence this dimension are: (i) economic feasibility - this aspect requires an assessment of the cost benefit to determine feasibility, and the expected transactional returns to determine whether a competitive advantage can be created; (ii) organisational factors - these relate to top management support, IT literacy and skill, user personas, and innovation experience; and (iii) IT infrastructure - this relates to the physical and virtual IT requirements, and includes considerations for computing, information management and communication platforms, and ICT services, both shared and dedicated [27].

\subsection{Unified theory of acceptance and use of technology (UTAUT)}

The unified theory of acceptance and use of technology (UTAUT) was the result of research done by Venkatesh et al. [14]. The purpose of the research was to consolidate the fragmented theory on individual-level technology acceptance. UTAUT is the culmination of the integration of research on eight specific technology-acceptance models: IDT, TRA, TAM, TPB, C-TAM-TPB, MPCU, MM, and SCT. The causes of intention and use of information technology were compared to find conceptual and empirical similarities across these models. In this unified theory, four consolidated constructs were theorised to be determinants of behavioural intent: (i) performance expectancy, (ii) effort expectancy, (iii) social influence, and (iv) facilitating conditions. The model also included gender, age, experience, and voluntariness of use as moderators - see Figure 5.

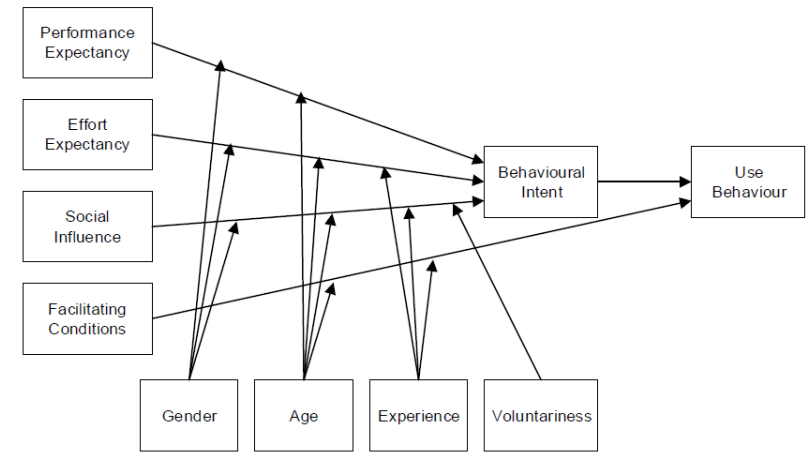

Figure 5: UTAUT model [14]

UTAUT has, since its original publication, been applied in various studies. Venkatesh, Thong and Xu [29] cite various studies in which the model has been applied and replicated in an organisational setting, mainly for three types of extensions and integrations: (i) Application in new contexts that include new technology, new user populations, and new cultural settings; (ii) expanded constructs to improve the theoretical mechanisms outlined in UTAUT; and (iii) the inclusion of exogenous predictors of UTAUT.

Although various studies have been conducted in an organisational context, they have all been done on an individual level and have mainly focused on a B2E channel. Venkatesh et al. [29] expanded this channel to a B2C context. No literature could be found for the application of UTAUT, or an adaptation of UTAUT, at a firm level. 
A literature review and analysis uncovered various technology-adoption frameworks and models that have been used to study the adoption of various technologies in numerous contexts. This review also examined the various factors that influence adoption and, where possible, the firm-level adaptation of the model was also presented. The theories and models described below have been identified as the major contributors to the technology adoption and diffusion research field. Davis' [30] technology acceptance model (TAM) was built on the premise that, when a user was presented with a technology, the perceived usefulness (PU) and the perceived ease of use (PEOU) would determine whether or not they would accept the technology. The theory was later adapted to include the effects of social influence and moderating factors [14]. Rogers' innovation diffusion theory (IDT) [15] sees innovations as being transferred through certain channels over time and within a particular culture. Moore and Benbasat [31] later adapted the innovation characteristics for information systems to define a set of constructs that could be used to study individual technology acceptance. IDT has also been adapted to study firm-level innovativeness. The firm's level of innovation is related to independent variables that are associated with individual (leader) characteristics, internal organisational structural characteristics, and the external characteristics of the organisation. Tornatzky and Fleischer's technology-organisation-environment (TOE) [24] framework was specifically developed to deal with aspects that influence the process of the adoption and implementation of technological innovation in an organisational context. The three aspects on which this model focuses are the technological, organisational, and environmental contexts. Tjan's fit viability model (FVM) [26] uses dimensions of fit and viability to evaluate internet initiatives. The theoretical foundation for the fit dimension is the task-technology-fit (TTF) perspective that was introduced by Goodhue and Thompson [28]. The viability construct refers to the extent to which the organisation is ready for technology adoption, taking general economic feasibility, technical infrastructure, and social readiness into consideration. Venkatesh et al. [14] introduced the unified theory of acceptance and use of technology (UTAUT) as a unified theory on the most significant constructs from social cognitive theory (SCT), the IDT, the model of personal computer utilisation (MPCU), the theory of planned behaviour (TPB), the motivation model, the TAM, and the theory of reasoned action (TRA). UTAUT theorises that performance expectancy, effort expectancy, and social influence determine behaviour intent for information technology adoption. It also predicts that facilitating conditions as the fourth construct would influence use behaviour but not behaviour intent. The use of institutional theory, the model of lacovou, Benbasat and Dexter [32], and Basole's mobile enterprise readiness model [33] were examined as additional theories that could be combined with popular theories to provide a richer understanding of technology-adoption behaviour. A review of the current literature revealed that there is a need for a consolidation and synthesis of technology-adoption frameworks at a firm level in order to progress technology-adoption theory for researchers and practitioners interested in organisational technology-adoption behaviour. This article proposes a conceptual framework for technology adoption at a firm level. The model also presents a unification of firm-level constructs from TAM, IDT, TOE, FVM, and UTAUT.

\subsection{Factors affecting technology adoption at a firm level}

\subsubsection{Effect of performance utility on technology adoption}

Performance utility is defined as the degree to which an organisation believes that adopting the technology will lead to improved organisational performance. The six different constructs from previous research that pertain to performance utility are: perceived usefulness (TAM), relative advantage (IDT), technology context (TOE), viability (FVM), performance expectancy (UTAUT), and perceived benefits (EDIAM). The conceptual framework is illustrated in Figure 6.

Various studies have reported that the positive perceptions of the benefits of a technology can act as an incentive for the adoption of the technology [19, 34, 35]. Scornavacca and Barnes [1] suggest that the need for organisations to reduce latency, increase speed of response, enhance efficiency of operations and workforce, improve productivity, boost revenues, and increase competitive advantage will motivate organisations to adopt mobile enterprise applications. This study hypothesises that the expected benefits of MEA will have a positive effect on the adoption of this technology by organisations. 


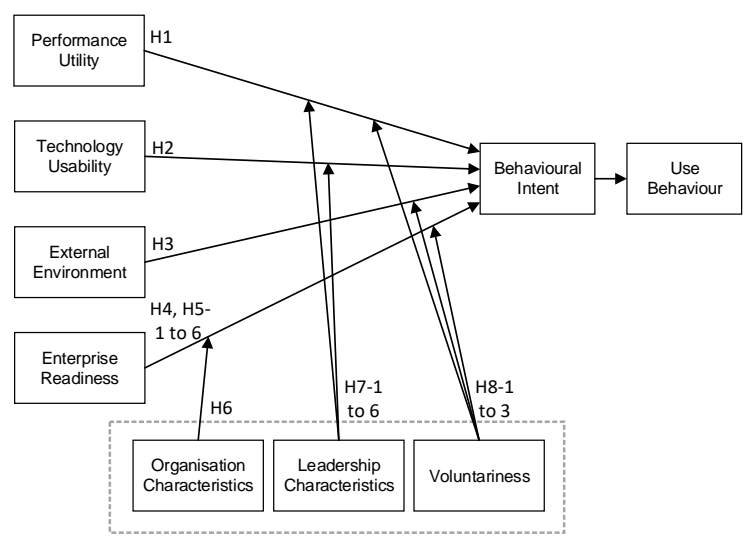

Figure 6: Conceptual framework for firm-level technology adoption.

Hypothesis $\mathbf{H 1}$ - Performance utility will have a positive effect on MEA adoption.

\subsubsection{Effect of technology usability on technology adoption}

Technology usability is defined as the degree to which an organisation believes that a technology is learnable, and the degree of effectiveness and efficiency with which the technology can be integrated. The four different constructs that pertain to technology usability from previous models are: perceived ease of use (TAM), complexity (IDT), technology context (TOE), and effort expectancy (UTAUT).

Awa, Ukoha and Emecheta [36] reported that studies done by Venkatesh et al. [14] and Clarke [9] support the theory that the usability or ease of use of a technology positively affects the intention to adopt the technology. This is because more complex applications are seen as riskier to implement. This study hypothesises that the perceived usability of a MEA will have an effect on the adoption of this technology by organisations.

Hypothesis H2 - Technology usability will have a positive effect on MEA adoption.

\subsubsection{Effect of external environment on technology adoption}

External environment is defined as the degree to which an organisation believes that environmental factors, for the milieu in which the firm operates, encourage technology-adoption initiatives. The different constructs that pertain to the external environment from previous models are: subjective norms (TAM), observability and external organisation structure characteristics (IDT), environmental context (TOE), social influence (UTAUT), external pressure (EDIAM), and isomorphic pressure (institutional theory). These environmental factors include peer influence, rate of technology change, market volatility, consumer readiness, competitive pressure, trading partner readiness, and regulatory requirements $[12,34,36]$.

Martín et al. [12] refer to a study done by Shankar et al. [37] in which competitive pressure is cited as a significant factor that influences the growth and spread of mobile commerce. In this study, it is mentioned that isomorphic pressures are forcing firms to adopt technology at the risk of creating a productivity paradox. This is a phenomenon where technology-adoption practices lead to the loss of productivity instead of an increase. At the other end of the spectrum, studies referred to in Martin et al. [12] state that, when firms are engaged in a sector with fierce rivalry and uncertainty about their competitors' actions, they are more inclined to adapt their technology strategies.

Hypothesis H3 - External environment will have an influence on the adoption of MEA.

\subsubsection{Effect of enterprise readiness on technology adoption}

Enterprise readiness refers to the degree to which an organisation believes that it has the ability to adopt, diffuse, and assimilate technology into its organisational structures. This includes the following enterprise readiness characteristics: technology infrastructure, leadership knowledge and support, resource availability (human, financial, and technical), organisational support processes, decision-maker knowledge, and employee readiness [19, 33]. 
The different constructs that pertain to enterprise readiness from the previous models are: firm characteristics (TAM), compatibility, trialability, internal organisational structure characteristics, and individual leader characteristics (IDT), organisational context (TOE), fit and viability (FVM), facilitating conditions (UTAUT), enterprise readiness (MERM), and organisation readiness (EDIAM)

Hypothesis $\mathrm{H4}$ - Enterprise readiness will have a positive effect on the adoption of MEA.

Lin and Lin [34] refer to studies done by Fielder, Grover and Teng [38] and Zu and Kramer [39] that confirm the link between sophisticated IS infrastructure and the increased probability of IS implementation success. It is therefore hypothesised that IS and IT infrastructure will influence an organisation's decision to adopt a technology.

Hypothesis H5-1 - Technology infrastructure readiness will have a positive effect on the adoption of MEA.

Rogers [15] stated that technology adoption has a greater probability of success when accepted in an organisation with greater compatibility between the technology and their processes. Lin and Lin [34] reaffirm the disruptive effect that radical technology adoptions can have on business processes, and also suggest that an improved synthesis will occur in organisations that adopt technology components supported by their processes. Process readiness refers to an organisation's degree of task technology fit.

Hypothesis H5-2 - Process readiness will have a positive effect on the adoption of MEA.

A firm's strategy plays a major role in their approach to technology adoption. Firms can focus on cost-cutting strategies, business process reengineering practices, product differentiation strategies, or product expansion strategies. It is therefore anticipated that the innovation strategies employed by organisations will have an effect on their technology-adoption intent.

Hypothesis H5-3 - The technology strategy of an organisation will determine the adoption of MEA.

Basole [33] refers to employee readiness as an employee's attitude towards change, their level of skill, and their perceptions of the end user's benefits of using the technology. It is hypothesised that a high degree of employee readiness will lead to faster rates of technology adoption and diffusion.

Hypothesis H5-4 - Employee readiness will determine the adoption of MEA.

Lin and Lin [34] refer to studies done by Crook and Kumar [41], McGowan and Madey [42], and Chau and Tam [43], who all acknowledge that lack of IS expertise is a key factor impeding IS adoption and diffusion. Organisations adopting new technologies usually go through a process of knowledge discovery before analysing alternatives and finally making a decision. This process of knowledge discovery is important, because it creates an awareness of existing opportunities, challenges, and barriers. Once decision-makers have gone through this process of discovery, it is hypothesised that they will more readily adopt a technology that is believed to add value [13].

Hypothesis H5-5 - Knowledge readiness will determine the adoption of MEA.

Organisations need to have the ability to support initiatives pre- and post-implementation. It is therefore critical that organisations have sufficient financial, human, and technical resources available to ensure that technology assimilation is maximised [13].

Hypothesis H5-6 - Resource readiness will determine the adoption of MEA.

\subsection{Moderators, or the conceptual technology-adoption framework}

\subsubsection{Effect of organisational characteristics as a moderator}

Awa et al. [36] refer to several studies in which they found that firm size is a major factor that affects technology adoption. Bigger firms have a greater resilience in dealing with implementation failures, and smaller firms are more susceptible to the effects of resistance to change, lack of education, lack of trust in the security of transactions, lack of technological expertise, and lack of economic resources.

Hypothesis $\mathrm{H6}$ - Firm size will moderate the effect of enterprise readiness on MEA adoption. 


\subsubsection{Effect of leadership characteristics as a moderator}

It has been found that age directly impacts on the perceptions of performance utility and technology usability. Studies [43, 44] report that younger executives appear much more inclined to chase corporate growth strategies, as they are predisposed to a greater risk-taking disposition.

Hypotheses H7-1 and H7-2 - Leadership age will determine the performance utility and technology usability for the adoption of MEA.

A study done by Gefen and Straub [45] found that gender predicts performance utility and technology usability. Venkatesh and Morris [44] continued that research by examining gender differences in individual perceptions of performance utility and technology usability of information technology. Their study concluded that men consider performance utility to be more important than women in making their adoption decision, while women perceive technology usability to be more important than do men.

Hypotheses H7-3 and H7-4 - Leadership gender will determine the performance utility and technology usability for the adoption of MEA.

Awa et al. [36] refer to studies done by Becker (1970) and Hambrick and Mason (1984) that validate how education influences personal innovativeness, belief/value systems, risk-taking, cognitive preferences, and receptivity to an innovation. It is therefore hypothesised that education will have an influence on the performance utility and technology usability constructs of the conceptual framework.

Hypotheses H7-5 and H7-6 - Leadership education will determine the performance utility and technology usability for the adoption of MEA.

\subsubsection{Effect of a voluntary vs mandatory setting as a moderator at firm level}

Prior studies suggested that it is possible for technology adoption to be influenced in two ways: directly through compliance, or indirectly through its effect on beliefs of performance utility. Compliance relates directly to the level of voluntariness. In an organisational setting, employees have to comply with the organisation's demands [46]. The role of voluntariness has been tested to establish its influence on the link between social norms (SN) and behaviour intent (BI), and it was confirmed that SN have an influence on intentions for the mandatory but not for the voluntary use context. SN can influence intention through internalisation, which is the process in which an important referent believes that the system should be used and, as a result, this belief is incorporated into one's own belief structure [47]. 'Referent' in the context of this study can be internal employees that hold a high regard for decision-makers, or they can be shareholders.

A study done by Brown, Massey, Montoya-Weiss and Burkman [48], in a setting where technology was mandatory, found that technology usability could have a more profound impact on technology adoption than performance utility. This could be explained by the fact that, in a non-voluntary setting, the ease with which a technology can be used will outweigh the usefulness of the technology, since the usefulness could be hidden from the end user by bureaucratic requirements.

Hypotheses H8-1, H8-2, and H8-3 - Voluntariness will moderate the effect of enterprise readiness, performance utility, and technology usability on adoption intent of MEA.

\section{RESEARCH METHODOLOGY}

This research uses a sample survey methodology to test the research hypotheses and the proposed model's construct validity and reliability. A theoretical grounded questionnaire is developed from previous studies, through a broad literature review, and used as the measurement instrument. A list of possible measurement items is identified and adapted for this study. Where items are adapted or new items are developed, they are checked for reliability using strict procedures. The sections that follow describe the research sample, instrument development, and reliability analysis.

\subsection{Sample and procedure}

The questionnaire developed was administered through an online survey platform. Using this platform, a contact list of 743 business owners, executives, and senior managers was imported, and a link to the online survey was e-mailed via the platform to all contacts. The survey was set to track 
responses using IP addresses and device information to ensure that no duplicate responses would be logged.

\subsubsection{Data gathered}

Of the 743 distributed surveys, 69 responses were received. Only one response was received from the public forum posting. A total of 70 responses was thus received. Validation of the completeness of responses revealed that nine responses were incomplete and therefore not usable. Validation to exclude organisations not based in South Africa (where 'based in South Africa' is defined as having a registered company operating in South Africa) was also conducted, and revealed one response that did not meet this criterion. In total, 60 complete and usable questionnaires were returned. This response rate represents a total response rate of 9.4 per cent and a valid response rate of 8.1 per cent. Previous studies reported response rates of between 11.5 per cent [19] and 36.7 per cent [49], which makes this survey's response rate lower than would have been expected. All responses received were from managers, executives, or owners.

\subsubsection{Descriptive statistics}

Table 1 summarises the demographic attributes of the respondents' information. Most of the responses were from males between the ages of 30 and 39, which accounted for 45 per cent of the responses obtained. There is a disproportionate response rate between males and females, with only 16.67 per cent of responses coming from females. $80 \%$ per cent of the respondents said, under education, that they had some form of degree. All respondents were employed as managers, executives, or owners at the time of the survey. The sample was almost evenly split between small and medium enterprises (SMEs) - representing 41.67 per cent of the sample - and large to corporate enterprise organisations, representing 58.33 per cent of the sample. 51.67 per cent of the organisations represented in the study came from three industries: telecommunications, technology, internet and electronics (25\%); finance and financial services (15\%); and manufacturing (11.67\%), with the remainder represented by the other 14 industries. 86.67 per cent of the organisations that responded had a male-dominated leadership structure, and 86.67 per cent were college or university graduates. 83.3 per cent of the leadership were between the ages of 40 and 59 .

\subsection{Instrument development}

The questionnaire developed for this study was divided into three sections (see Appendix 2). The first section captures the demographic and general organisational information of the respondents. In the second section, seven-point Likert scales with end points of 'strongly disagree' [1] and 'strongly agree' [7] were used to examine participants' responses to statements of the questionnaire that captured attitudinal responses for all the constructs. Measurement items for actual usage (AU), behavioural intent $(\mathrm{BI})$, performance utility $(\mathrm{PU})$, technology usability $(\mathrm{TU})$, external environment (EE), and enterprise readiness (ER) were all adapted from previous studies [14, 19, 34, 35, 48]. In the third section of the questionnaire, the moderating factors for organisational characteristics, leadership characteristics, and voluntariness were recorded.

\subsection{Reliability}

Construct validation was performed through factor analysis (FA) using principal component analysis (PCA), and reliability testing using Cronbach's alpha. Variable loadings on each construct were analysed to determine whether the conditions for convergent validity existed. It was found that PU and TU variables loaded on distinct primary factors, indicating that the conditions for convergent validity existed and that the measurement variables were good predictors for these constructs. Factor analysis for the EE construct revealed that the measurement variables loaded on two factors. Analysis of the factor loadings, and face value interpretation of the variable, revealed inherent ambiguity in the way that measurement item EE4 was asked. After this factor was removed, the analysis revealed that EE5 did not meet the minimum criteria for variable retention, and this variable was also removed. The three remaining variables loaded on a unique primary factor, indicating that the conditions for convergent validity existed and that the remaining measurement variables were good predictors for the EE construct. Factor analysis for the variables measuring ER revealed several variables that did not meet the minimum criteria for variable retention, and variables ERRF, ERL1, ERL2, and ERS1 were removed from the model. The 13 remaining variables loaded on four factors that revealed the existence of four sub-constructs within the ER construct. Factor loading for the remaining variables within the sub-constructs indicated that the conditions for convergent validity existed, and that the remaining sub-constructs were good predictors for the ER construct. Table 2 summarises the validity and reliability findings for the research instrument. 
Table 1: Demographic attributes of respondents' characteristics

\begin{tabular}{|c|c|c|c|}
\hline \multirow{2}{*}{ Measure } & \multirow{2}{*}{ Items } & \multicolumn{2}{|c|}{ Subjects } \\
\hline & & Frequency & Percentage \\
\hline \multirow[t]{7}{*}{ Age } & $<20$ & 0 & 0.00 \\
\hline & $20-29$ & 3 & 5.00 \\
\hline & $30-39$ & 31 & 51.67 \\
\hline & $40-49$ & 10 & 16.67 \\
\hline & $50-59$ & 12 & 20.00 \\
\hline & $60-69$ & 4 & 6.67 \\
\hline & $>70$ & 0 & 0.00 \\
\hline \multirow[t]{2}{*}{ Gender } & Female & 10 & 16.67 \\
\hline & Male & 50 & 83.33 \\
\hline \multirow[t]{6}{*}{ Education } & High school & 2 & 3.33 \\
\hline & Some college - no degree & 10 & 16.67 \\
\hline & Associate degree & 3 & 5.00 \\
\hline & Bachelor's degree & 30 & 50.00 \\
\hline & Doctoral degree & 1 & 1.67 \\
\hline & Master's degree & 14 & 23.33 \\
\hline \multirow[t]{3}{*}{ Position } & Middle management & 16 & 26.67 \\
\hline & Senior management & 20 & 33.33 \\
\hline & Owner/executive/C-level & 24 & 40.00 \\
\hline \multirow[t]{5}{*}{ Size } & $0-10$ & 6 & 10.00 \\
\hline & $11-50$ & 12 & 20.00 \\
\hline & $51-250$ & 7 & 11.67 \\
\hline & $251-1000$ & 10 & 16.67 \\
\hline & $>1000$ & 25 & 41.67 \\
\hline \multirow{18}{*}{ Industry } & Advertising \& marketing & 1 & 1.67 \\
\hline & Agriculture & 2 & 3.33 \\
\hline & Airlines \& aerospace (including defence) & 1 & 1.67 \\
\hline & Automotive & 1 & 1.67 \\
\hline & Business support \& logistics & 5 & 8.33 \\
\hline & Construction, machinery, and homes & 3 & 5.00 \\
\hline & Education & 2 & 3.33 \\
\hline & Entertainment \& leisure & 1 & 1.67 \\
\hline & Finance \& financial services & 9 & 15.00 \\
\hline & Food \& beverages & 1 & 1.67 \\
\hline & Healthcare \& pharmaceuticals & 2 & 3.33 \\
\hline & Insurance & 1 & 1.67 \\
\hline & Manufacturing & 7 & 11.67 \\
\hline & Retail \& consumer durables & 1 & 1.67 \\
\hline & Telecommunications, technology, internet \& & & \\
\hline & electronics & 15 & 25.00 \\
\hline & Transportation \& delivery & 4 & 6.67 \\
\hline & Utilities, energy, and extraction & 4 & 6.67 \\
\hline Leadership & $20-29$ & 2 & 3.33 \\
\hline \multirow[t]{5}{*}{ Age } & $30-39$ & 6 & 10.00 \\
\hline & $40-49$ & 26 & 43.33 \\
\hline & $50-59$ & 24 & 40.00 \\
\hline & $60-69$ & 1 & 1.67 \\
\hline & $>70$ & 1 & 1.67 \\
\hline Leadership & Female & 2 & 3.33 \\
\hline \multirow[t]{2}{*}{ Gender } & Male & 52 & 86.67 \\
\hline & There is an even split & 6 & 10.00 \\
\hline Leadership & High school & 2 & 3.33 \\
\hline \multirow[t]{4}{*}{ Education } & Some college - no degree & 6 & 10.00 \\
\hline & Associate degree & 4 & 6.67 \\
\hline & Bachelor's degree & 40 & 66.67 \\
\hline & Master's degree & 8 & 13.33 \\
\hline
\end{tabular}


Table 2: Factor analysis summary

\begin{tabular}{|c|c|c|c|c|c|c|}
\hline Construct & Sub construct & Variable & $\begin{array}{l}\text { Factor } \\
\text { loading }\end{array}$ & Eigen & Variance & $\begin{array}{l}\text { Cronbach's } \\
\text { a }\end{array}$ \\
\hline \multirow[t]{7}{*}{ PU } & \multirow[t]{7}{*}{ None } & PU1 & 0.845 & \multirow[t]{7}{*}{4.954} & \multirow[t]{7}{*}{70.78} & \multirow[t]{7}{*}{0.931} \\
\hline & & PU2 & 0.864 & & & \\
\hline & & PU3 & 0.845 & & & \\
\hline & & PU4 & 0.855 & & & \\
\hline & & PU5 & 0.851 & & & \\
\hline & & PU6 & 0.788 & & & \\
\hline & & PU7 & 0.839 & & & \\
\hline \multirow[t]{4}{*}{ TU } & \multirow[t]{4}{*}{ None } & TU1 & 0.891 & \multirow[t]{4}{*}{3.029} & \multirow[t]{4}{*}{75.74} & \multirow[t]{4}{*}{0.893} \\
\hline & & TU2 & 0.878 & & & \\
\hline & & TU3 & 0.844 & & & \\
\hline & & TU4 & 0.867 & & & \\
\hline \multirow[t]{3}{*}{$\mathrm{EE}$} & \multirow[t]{3}{*}{ None } & EE1 & 0.877 & \multirow[t]{3}{*}{2.224} & \multirow[t]{3}{*}{74.12} & \multirow[t]{3}{*}{0.825} \\
\hline & & EE2 & 0.829 & & & \\
\hline & & EE3 & 0.875 & & & \\
\hline \multirow[t]{13}{*}{ ER } & \multirow[t]{2}{*}{ IT infrastructure (D3) } & ERIT1 & 0.812 & \multirow[t]{2}{*}{5.105} & \multirow[t]{2}{*}{39.27} & \multirow[t]{2}{*}{0.731} \\
\hline & & ERIT2 & 0.860 & & & \\
\hline & \multirow{4}{*}{$\begin{array}{l}\text { Organisational policies, processes, } \\
\text { and systems (D2) }\end{array}$} & ERIT3 & 0.873 & \multirow[t]{4}{*}{2.355} & \multirow[t]{4}{*}{57.38} & \multirow[t]{4}{*}{0.892} \\
\hline & & ERIT4 & 0.858 & & & \\
\hline & & ERP1 & 0.854 & & & \\
\hline & & ERP2 & 0.807 & & & \\
\hline & \multirow{5}{*}{$\begin{array}{l}\text { Employee knowledge and readiness } \\
\text { (D1) }\end{array}$} & ERE1 & 0.823 & \multirow[t]{5}{*}{1.473} & \multirow[t]{5}{*}{68.72} & \multirow[t]{5}{*}{0.871} \\
\hline & & ERE2 & 0.773 & & & \\
\hline & & ERE3 & 0.821 & & & \\
\hline & & ERK1 & 0.827 & & & \\
\hline & & ERK2 & 0.610 & & & \\
\hline & \multirow[t]{2}{*}{ Organisational resources (D4) } & ERRH & 0.815 & \multirow[t]{2}{*}{1.004} & \multirow[t]{2}{*}{76.44} & \multirow[t]{2}{*}{0.737} \\
\hline & & ERRT & 0.784 & & & \\
\hline
\end{tabular}

\section{$5 \quad$ RESULTS AND DISCUSSION}

Table 3 shows the results of the hypotheses. Eight out of the nine hypotheses that related to the model's primary constructs and sub-constructs exhibited a p-value less than 0.05 . The remaining sub-construct for innovation strategy could not be analysed as a result of variable reduction that removed the construct's measurements items during the factor analysis; this therefore remains unconfirmed.

The following were found to be significant predictors of the adoption intent of MEA technology in South African organisations:

- The degree to which an organisation believes that adopting the technology will lead to improved organisational performance.

- The degree to which an organisation believes that a technology is learnable, and the degree of effectiveness and efficiency with which the technology can be integrated into their existing environment.

- The degree to which an organisation believes that environmental factors for the milieu in which the firm is operating encourage technology-adoption initiatives.

- The degree that an organisation believes that it has the ability to adopt, diffuse, and assimilate technology into its organisational structures, which include IT infrastructure, organisational policies, processes and systems, employee knowledge and readiness, and organisational resources.

Contrary to the hypotheses, none of the moderating variables for organisational characteristics (size of the organisation), leadership characteristics (age, gender, and level of education), and voluntariness were found to significantly moderate the degree to which performance utility, technology usability, and enterprise readiness predicted mobile enterprise application adoption intent. 
Table 3: Regression test results

\begin{tabular}{|c|c|c|c|c|c|c|}
\hline $\begin{array}{l}\text { Dependent } \\
\text { variable }\end{array}$ & $\begin{array}{l}{ }^{*} \text { Independent } \\
\text { Variable }\end{array}$ & $\begin{array}{l}\text { Wald } \\
\mathrm{Chi}^{2}\end{array}$ & $\mathrm{P}>\mathrm{Chi}^{2}$ & Hypothesis & Result & $\begin{array}{l}\text { Predictability } \\
\text { accuracy }\end{array}$ \\
\hline \multirow[t]{18}{*}{$\begin{array}{l}\text { Adoption } \\
\text { intent }\end{array}$} & PU & 6.354 & $0.012^{*}$ & $\mathrm{H} 1$ & Accepted & 81.67 \\
\hline & TU & 5.693 & $0.017^{*}$ & $\mathrm{H} 2$ & Accepted & 75.00 \\
\hline & $\mathrm{EE}$ & 9.464 & $0.002^{* *}$ & $\mathrm{H} 3$ & Accepted & 80.00 \\
\hline & ER & 10.915 & $0.001^{* * *}$ & $\mathrm{H} 4$ & Accepted & 86.67 \\
\hline & D3 & 3.905 & $0.048^{*}$ & H5-1 & Accepted & 73.33 \\
\hline & D2 & 8.507 & $0.004^{* *}$ & H5-2 & Accepted & 80.00 \\
\hline & ERS1 & $\mathrm{N} / \mathrm{A}$ & $\mathrm{N} / \mathrm{A}$ & $\mathrm{H} 5-3$ & Unconfirmed & - \\
\hline & D1 & 7.661 & $0.006^{* *}$ & H5-4\& H5-5 & Accepted & 76.67 \\
\hline & D4 & 10.313 & $0.001^{* * *}$ & H5-6 & Accepted & 76.67 \\
\hline & SIZE $\times$ ER & 1.996 & 0.158 & $\mathrm{H} 6$ & Rejected & \\
\hline & PU $\times$ AGE & 0.777 & 0.378 & $\mathrm{H} 7-1$ & Rejected & \\
\hline & TU $\times$ AGE & 0.415 & 0.520 & $\mathrm{H} 7-2$ & Rejected & \\
\hline & $\mathrm{PU} \times \mathrm{GEN}$ & 0.057 & 0.812 & $\mathrm{H} 7-3$ & Rejected & \\
\hline & TU $\times$ GEN & 0.347 & 0.556 & $\mathrm{H} 7-4$ & Rejected & \\
\hline & PU $x$ EDU & 0.085 & 0.770 & $\mathrm{H} 7-5$ & Rejected & \\
\hline & TU x EDU & 0.004 & 0.952 & $\mathrm{H} 7-6$ & Rejected & \\
\hline & ER $\times$ SET & 0.010 & 0.921 & H8-1 & Rejected & \\
\hline & TU $\times$ SET & 0.816 & 0.366 & H8-2 & Rejected & \\
\hline
\end{tabular}

*PU (performance utility); TU (technology usability); EE (external environment); ER (enterprise readiness); D (demographic); GEN (gender)

See also Appendix 2 - Research instrument for additional information on abbreviations.

\subsection{Relationship between PU, TU, EE, and ER on adoption intent}

This study specifically investigated the relationship between performance utility, technology usability, external environment, and enterprise readiness with adoption intent for mobile enterprise applications at a firm level. The findings indicate that the hypotheses for the links between PU, TU, $\mathrm{EE}$, and ER with adoption intent are substantiated.

As with previous technology-adoption studies, this research supports the notion that a positive relationship exists between factors that inform an organisation's views on technology performance utility (PU) and technology usability (TU), and the organisation's intent to adopt said technology. This study reinforces the view that the need for organisations to reduce latency, increase speed of response, enhance efficiency of operations and workforce, improve productivity, boost revenues, integrate easily, and ensure fast efficient adoption will act as a motivational factor to adopt mobile enterprise applications.

Results for this study show that factors originating in the external environment have a significant impact on an organisation's MEA technology-adoption intent. This is in accordance with various studies that used TAM, TOE, IDT, and UTAUT to measure the effect of environment factors, including peer influence, rate of technology change, market volatility, consumer readiness, competitive pressure, trading partner readiness, and regulatory requirements. This research study confirms earlier studies that firm characteristics (TAM), compatibility, trialability, internal organisational structure characteristics and individual leader characteristics (IDT), organisation context (TOE), fit and viability (FVM), facilitating conditions (UTAUT), enterprise readiness (MERM), and organisation readiness (EDIAM) will have a significant impact on an organisation's intent to adopt MEA technology. Enterprise readiness was developed as a unified construct that would measure these factors. It is therefore important to understand that organisations need to believe that they have the ability to adopt, diffuse, and assimilate MEA technology into their organisational structures. 
Six sub-constructs were posited, but factor analysis revealed the existence of four. Organisational innovation strategy was removed because the minimum number of items required to measure the sub-construct was not included in the original research instrument. Only one factor was used in the research instrument; it has, however, been suggested that at least three items should be used for confirmatory factor analysis to be effective. The original research model posited that employee understanding and employee knowledge are two distinct sub-constructs. However, factor analysis revealed that they grouped closely, and they were therefore combined into one sub-construct. This was accepted as a logical grouping because the measures were so closely related to employee characteristics. It was thought that the IT systems readiness measure would group with the IT infrastructure sub-constructs, but factor analysis revealed that the measures for process, systems, and policy readiness grouped together. This was also accepted as a logical grouping because of the alignment of the measures to a factor that group business process drivers. The four sub-constructs - IT infrastructure, employee readiness and knowledge, organisational resources, and organisational process drivers - were all found to have a significant effect on an organisation's intent to adopt MEA technology.

It is noteworthy that sub-construct D1, which relates to the organisation's IT infrastructure readiness, was on the limit of reporting a significant finding with a value of $\mathrm{P}>\mathrm{Chi}^{2}$ value of 0.048 . This finding could be explained by the possibility that organisations at present do not see wireless network infrastructure as a prerequisite for mobile enterprise application adoption, because of the proliferation of $4 G$ and LTE networks that allow for effective mobile data transfer capability. It is anticipated, however, that this notion will be raised as the need for secured data transfers increases.

\subsection{Effects of age, gender, education, and voluntariness on adoption intent}

Interestingly, this study did not find support for the moderating effects of leadership age, gender, and level of education on the degree to which performance utility and technology usability inform an organisation's intent to adopt mobile enterprise application technology. Various earlier TAM studies have postulated and found support for the moderating effects that demographics have on PU and PEOU constructs. There have, however, also been various studies that have refuted the interaction effects of these variables on technology-adoption intent.

There are several reasons that could explain why this study did not find evidence to support the moderating effects of demographic variables on performance utility and technology usability. First, it has to be noted that the sample size used for this study could restrict the statistical significance of the moderating effect that these variables could have. Second, the technology chosen as the subject matter for this research project is different from that of previous studies, and as a result MEA could, in itself, be a technology that is not significantly impacted by the interaction effects of age, gender, and education. Wu and Wang [49] reported that the significance of ease of use diminishes over time, and this could be explained by the effect that maturing technology has on the user's confidence to use the technology. Extrapolating this notion to the use of mobile enterprise application technology, it could stand to reason that, because this technology type has already penetrated most smart phone adopters' lives in the form of non-enterprise-centric applications (such as private email apps, cloud storage apps, note-taking, and task reminder apps, etc.), the end-user base is already so familiar and confident with this type of technology across all demographic segments that the moderating effects are non-existent. It therefore stands to reason that largescale adoption of technology that is similar to new tech trends should show diminishing moderating effects as the technology diffusion rate reaches a maximum.

The setting in which the technology was introduced for the level of voluntariness that was afforded by organisations was also found to be a non-significant predictor. The limited sample size is cited as a possible reason that no statistical significance was found. An alternative explanation could be that technology adoption in an organisation is not subject to the same level of autonomy as non-businesscentric applications. A major driver in MEA technology adoption is the need for organisations to improve business processes, and underlying this is the standardisation of these business processes. This would mean that, in order for organisations to implement business process improvement changes effectively, they would need to standardise processes, which would require the standardisation of work practices; and where information systems are required to perform business tasks, it would mean that the interaction with the technology would not be voluntary. Business process standardisation is, however, mostly associated with larger organisations, as it stands to reason that diverse business practices require a standardised process to ensure organisational 
compliance with policies. It would therefore be interesting to see whether a moderating effect for the technology setting (voluntariness) and size exists for PU, TU, and ER.

\subsection{Research limitations}

Although this study provided interesting insight into the factors that affect the intention of organisations to adopt MEA technology, it is important to mention that this research study has several limitations: (i) due to the limited number of responses obtained, this study may not be representative of all organisations in South Africa, and the results can therefore not be generalised; (ii) this study was limited to the South African organisational landscape and, as a result, the findings may not apply to countries that do not share a similar socio-economic system; (iii) the study was not conducted as a longitudinal study, and therefore did not measure the link between adoption intent and actual usage over time; (iv) certain sub-constructs were measured using one or two items, and as a result did not exhibit adequate reliability for factorial validity, which necessitated their removal; and $(v)$ the model as a whole was not validated using structural equation modelling, which has been one of the primary methods used in TAM studies to validate models.

\section{CONCLUSION}

This article proposed an integrated and unified conceptual framework for technology adoption at a firm level. The framework presents a unification of firm-level constructs from various other technology-adoption models, and theories such as the technology acceptance model (TAM), innovation diffusion theory (IDT), technology, organisation, and environment (TOE) model, fit viability model (FVM), and the unified theory of acceptance and use of technology (UTAUT). This research model then examined the influence of performance utility (PU), technology usability (TU), external environmental factors (EE), and enterprise readiness (ER) on technology adoption and diffusion of mobile enterprise application technology in an organisational context. The moderating effects of leadership age, gender, education, and the level of voluntariness of use were explored. Hypotheses were formulated from the model to investigate the relations between the model constructs.

A factor analysis was performed on the research instrument to validate its reliability. Using the principal component analysis method, the variable loadings on each construct were analysed to determine whether the conditions for convergent validity existed. Thereafter the hypotheses formulated in the conceptual framework were tested using logistic regression. The results and findings were discussed for greater managerial insight.

\section{RECOMMENDATIONS FOR FUTURE RESEARCH}

At the onset of this study, one of the research hypotheses was to determine the effect that an organisation's level of innovativeness would have on the adoption of new technology. Various studies have mentioned the need for future research to contribute to the understanding of the role that consumer innovativeness plays in technology-adoption theory. For this reason, it is proposed that future research at a firm level include specific measures for firm innovativeness to ensure that the effects of this construct on adoption intent are better understood. Although this study provided interesting insights into the factors affecting the intention to use MEA, it has some limitations: (i) it did not determine the change in user reactions over time; (ii) the exposure of MEA is still in its early stages, and the types of application are limited. Insufficient understanding of MEA and its applications will lower organisations' intention to use it; and (iii) data used in the study was selfreported; as a result, the sample may not be fully representative of the entire population.

\section{REFERENCES}

[1] Scornavacca, E. \& Barnes, S.J. 2008. The strategic value of enterprise mobility: Case study insights. Information, Knowledge, Systems Management, (7)1, 227-241.

[2] Gilbert, P. 2019. Mobile lags in SA online shopping. IT Web Business technology media company. https: / /www.itweb.co.za/content/G98YdMLxVVEMX2PD?utm_source=enewslead\&utm_medium=email [accessed 27 March 2019].

[3] Basole, R.C. 2004. The value and impact of mobile information and communication technologies. IFAC Symposium on Analysis, Modelling \& Evaluation of Human-Machine Systems, Atlanta, GA.

[4] Davidson, W. 1999. Beyond re-engineering: The three phases of business transformation. IBM Systems Journal, 38(2), 485. 
[5] Kornak, A., Teutloff, J. \& Welin-Berger, M. 2004. Enterprise guide to gaining business value from mobile technologies. Wiley Publishing, NY: USA.

[6] Murray, A. 2014. Where the enterprise mobility market stands today. http://www.apperian.com/wherethe-enterprise-mobility-market-stands-today/ [Accessed 10 March 2015].

[7] Briggs, B. \& White, M. 2012. Tech trends 2012: Elevate IT for digital business. Available from: http://www2.deloitte.com/us/en/pages/technology/articles/technology-consulting-tech-trendscollection.html [Accessed 01 March 2015].

[8] Bal, S.N. 2013. Mobile web: Enterprise application advantages. International Journal of Computer Science and Mobile Computing, 2(2), 36-40.

[9] Clarke, I.I. 2001. Emerging value propositions for m-commerce. Journal of Business Strategies, 18(2), 13349.

[10] Heng-Sheng, T. \& Gururajan, R. 2005. Mobile business: An exploratory study to define a framework for the transformation process. Proceedings of the $10^{\text {th }}$ annual conference of Asia-Pacific Decision Sciences Institute (APDSI), Taiwan, ISBN: 1539-1191.

[11] Jin, L., Deng, X. \& Lea, B. 2014. An explorative study of mobile apps in the enterprise. Twentieth Americas Conference on Information Systems, Savannah.

[12] Martín, S.S., López-Catalán, B. \& Ramón-Jerónimo, M.A. 2012. Factors determining firms’ perceived performance of mobile commerce. Industrial Management \& Data Systems, 112(6), 946-963.

[13] Basole, R.C. 2005. Mobilizing the enterprise: A conceptual model of transformational value and enterprise readiness. 26th ASEM National Conference Proceedings. 26-29 October 2005, Virginia Beach, Virginia.

[14] Venkatesh, V., Morris, M.G., Davis, F.D. \& Davis, G.B. 2003. User acceptance of information technology: Toward a unified view. MIS Quarterly, 27(3), 425-478.

[15] Rogers, E.M. 1962. Diffusion of innovations. Glencoe: Free Press.

[16] Venkatesh, V., Davis, F.D. \& Morris, M.G. 2007. Dead or alive? The development, trajectory and future of technology adoption research. Journal of the Association for Information Systems, 8(4), 268-286.

[17] Davis, F.D. 1986. A technology acceptance model for empirically testing new end-user information systems: Theory and results. PhD Thesis, Cambridge, MA: MIT Sloan School of Management.

[18] Davis, F.D. \& Venkatesh, V. 1996. A critical assessment of potential measurement biases in the technology assessment model: Three experiments. International Journal of Human-Computer studies, 45(1), 19-45.

[19] Yua, C.S. \& Tao, Y.H. 2008. Understanding business-level innovation technology adoption. Technovation, 29(2), 92-109.

[20] Oliveira, T. \& Martins, M.F. 2011. Literature review of information technology adoption models at firm level. The Electronic Journal Information Systems Evaluation, 14(1), 110-121.

[21] Greenhalgh, T., Robert, G., MacFarlane, F., Bate, P., Kyriakidou, O. \& Peacock, R. 2005. Storylines of research in diffusion of innovation: A meta-narrative approach to systematic review. Social Science \& Medicine, 61, 417-430.

[22] Damanpour, F. 1996. Organisational complexity and innovation: Developing and testing multiple contingency models. Management Science, 42(5), 693-716.

[23] Plsek, P. \& Greenhalgh, T. 2001. The challenge of complexity in health care. Complexity Science, 323, 625-628.

[24] Tornatzky, L.G. \& Fleischer, M. 1990. The processes of technological innovation. Lexington, MA: Lexington Books.

[25] Baker, J. 2012. Technology-organisation-environment framework. Integrated Series in Information Systems, 28, 231-245

[26] Tjan, A.K. 2001. Finally, a way to put your internet portfolio in order. Harvard Business Review, 79(2), 7685.

[27] Liang, P., Huang, C.W., Yeh, Y.H. \& Lin, B. 2007. Adoption of mobile technology in business: A fit-viability model. Industrial Management \& Data Systems, 107(8), 1154-1169.

[28] Goodhue, D.L. \& Thompson, R.L. 1995. Task-technology fit and individual performance. MIS Quarterly, 19(2), 213-236.

[29] Venkatesh, V., Thong, J.Y.L. \& Xu, X. 2012. Consumer acceptance and use of information technology: Extending the unified theory of acceptance and use of technology. MIS Quarterly, 36(1), 157-178.

[30] Davis, F.D. 1989. Perceived usefulness, perceived ease of use, and user acceptance of information technology. MIS Quarterly, 13(3), 319-340.

[31] Moore, G.C. \& Benbasat, I. 1991. Development of an instrument to measure the perceptions of adopting an information technology innovation. Information Systems Research, 2(3), 192-222.

[32] lacovou, C.L., Benbasat, I. \& Dexter, A.S. 1995. Electronic data interchange and small organisations: Adoption and impact of technology. MIS Quarterly, 19(4), 465-485.

[33] Basole, R.C. 2007. Strategic planning for enterprise mobility: A readiness centric approach. Americas Conference on Information Systems (AMCIS) Proceedings, Seattle, WA.

[34] Lin, H.F. \& Lin, S.M. 2008. Determinants of e-business diffusion: A test of the technology diffusion perspective. Technovation, 28(3), 135-145.

[35] Yang, K.C.C. 2005. Exploring factors affecting the adoption of mobile commerce in Singapore. Telematics and Informatics, 22(3), 257-277.

[36] Awa, H.O., Ukoha, O. \& Emecheta, B.C. 2015. Integrating TAM, TPB and TOE frameworks and expanding their characteristic constructs for e-commerce adoption by SMEs. Journal of Science \& Technology Policy Management, 6(2), 76-94.

[37] Shankar, V., Venkatesh, A., Hofacker, C. \& Naik, P. 2010. Mobile marketing in the retailing environment: Current insights and future research avenues. Journal of Interactive Marketing, 24(2), 111-20. 
[38] Fielder, K.D., Grover, V. \& Teng, J.T.C. 1996. An empirically derived taxonomy of information technology structure and its relationship to organizational structure. Journal of Management Information Systems, 13(1), 9-34.

[39] Zhu, K. \& Kraemer, K.L. 2002. E-commerce metrics for net-enhanced organizations: Assessing the value of e-commerce to firm performance in the manufacturing sector. Information Systems Research, 13(3), 275-295.

[40] Crook, C.W. \& Kumar, R.L. 1998. Electronic data interchange: A multiindustry investigation using grounded theory. Information \& Management, 34(2), 75-89.

[41] McGowan, M.K. \& Madey, G.R. 1998. The influence of organizational structure and organizational learning factors on the extent of EDI implementation in U.S. firms. Information Resource Management Journal, 11(3), 17-27.

[42] Chau, P.Y.K. \& Tam, K.Y. 1997. Factors affecting the adoption of open systems: An exploratory study. MIS Quarterly, 21(1), 1-24.

[43] Czaja, S. \& Sharit, J. 1998. Age difference in attitudes towards computer. Journal of Gerontology Series B: Psychological Sciences, 53(5), 329-341.

[44] Venkatesh, V. \& Morris, M. 2000. Why don't men ever stop to ask for directions? Gender, social influence and their role in technology acceptance and usage behavior. MIS Quarterly, 24(1), 115-139.

[45] Gefen, D. \& Straub, D.W. 1997. Gender differences in the perception and use of e mail: An extension to the technology acceptance model. MIS Quarterly, 21(4), 389-400.

[46] Sun, H. \& Zhang, P. 2006. The role of moderating factors in user technology acceptance. International Journal of Human-Computer Studies, 64(2), 53-78.

[47] Venkatesh, V. \& Davis, F.D. 2000. A theoretical extension of the technology acceptance model: Four longitudinal field studies. Management Science, 46(2), 186-204.

[48] Brown, S., Massey, A., Montoya-Weiss, M. \& Burkman, J. 2002. Do I really have to? User acceptance of mandated technology. European Journal of Information Systems, 11, 283-295.

[49] Wu, J.H. \& Wang, S.C. 2005. What drives mobile commerce? An empirical evaluation of the revised technology acceptance model. Information \& Management, 42, 719-29.

[50] Fishbein, M. \& Ajzen, I. 1975. Belief, attitude, intention, and behaviour: An introduction to theory and research. Reading, MA: Addison-Wesley.

[51] Li, L. 2010. A critical review of technology acceptance literature. 2010 Annual Meeting of the Southwest Decision Sciences Institute. Dallas, Texas.

[52] Ajzen, I. 1991. The theory of planned behavior. Organizational Behavior and Human Decision Processes, 50(2), 179-211.

[53] Venkatesh, V. \& Bala, H. 2008. Technology acceptance model 3 and a research agenda on interventions. Decision Sciences, 39(2), 273-315.

[54] Barnes, S.J. 2003. Enterprise mobility: Concept and examples. International Journal of Mobile Communications, 1(4), 341-359.

[55 Thompson, R.L., Higgins, C.A. \& Howell, J.M. 1991. Personal computing: Toward a conceptual model of utilization. MIS Quarterly, 15(1), 125-143.

[56] Bandura, A. 1986. Social foundations of thought and action: A social cognitive theory. Englewood Cliffs, N.J.: Prentice-Hall.

[57] Gebauer, J., Gribbons, M.L. \& Shaw, M.J. 2010. Task-technology fit for mobile information systems. Journal of Information Technology, 25, 259-272.

[58] Zigurs, I. \& Buckland, B.K. 1998. A theory of task-technology fit and group support systems effectiveness. MIS Quarterly, 22(3), 313-334.

[59] Davis, F.D. \& Warshaw, P.R. 1992. Extrinsic and intrinsic motivation to use computers in the workplace. Journal of Applied Social Psychology, 22(14), 1111-1132. 
Appendix 1: Table with summary of acceptance theory models

\begin{tabular}{|c|c|c|}
\hline Acceptance Theory & Description and History & Core Constructs \\
\hline $\begin{array}{l}\text { Theory of reasoned } \\
\text { action (TRA) }\end{array}$ & $\begin{array}{l}\text { Drawn from social psychology, TRA is seen as theory zero for } \\
\text { most influential theories of human behaviour. The theory was } \\
\text { proposed by Fishbein and Ajzen [50]. The core premise of TRA } \\
\text { suggests that a person's behavioural intention (BI) depends on } \\
\text { the person's attitude (A) about the behaviour and subjective } \\
\text { norms (SN): BI = A + SN. } \\
\text { Like economic behavioural theory TRA assumes that individuals } \\
\text { are rational decision makers who constantly calculate and } \\
\text { evaluate their beliefs in the process of forming their attitude } \\
\text { toward behaviour intent. To determine behavioural intent an } \\
\text { individual's normative belief strength are multiplied by the } \\
\text { motivation to comply with that antecedent, after which the } \\
\text { resulting set of weights are summed to determine behavioural } \\
\text { intention [51]. }\end{array}$ & $\begin{array}{ll}- & \text { Attitude } \\
- & \text { Behaviour intent } \\
- & \text { Subjective norm }\end{array}$ \\
\hline $\begin{array}{l}\text { Theory of planned } \\
\text { behaviour (TPB) }\end{array}$ & $\begin{array}{l}\text { TPB is an extension of TRA that was introduced by Ajzen [52]. } \\
\text { The extension was in the form of the introduction of an } \\
\text { additional construct that would explain behavioural control. } \\
\text { This extension was the result of observation that behaviour was } \\
\text { not always completely voluntary nor was it completed } \\
\text { controlled. TPB combined two core constructs from TRA: } \\
\text { Attitude towards behaviour and subjective norms together with } \\
\text { the new construct to predict behavioural intent. This in turn } \\
\text { would be used as a predictor for actual behaviour. It was } \\
\text { theorised that perceived behavioural control would also directly } \\
\text { impact on behaviour. Venkatesh et al. [14] reported studies by } \\
\text { Ajzen 1991; Harrison et al. 1997; Mathieson } 1991 \text { and Taylor and } \\
\text { Todd 1995b, that offered a review of several studies using TPB } \\
\text { to successfully predict intention and behaviour in a wide variety } \\
\text { of settings. }\end{array}$ & $\begin{array}{ll}- & \text { Attitude toward } \\
\text { behaviour } \\
\text { - } & \text { Subjective norms } \\
- & \text { Perceived } \\
\text { behavioural control }\end{array}$ \\
\hline $\begin{array}{l}\text { Technology acceptance } \\
\text { model } \\
\text { (TAM, TAM2 \& TAM3) }\end{array}$ & $\begin{array}{l}\text { TAM is an extension on TRA that was specifically tailored for the } \\
\text { Information Systems contexts. The first version of the theory } \\
\text { was introduced by Davis [17]. The theory was built on the } \\
\text { premise that when a user was presented with a technology, the } \\
\text { perceived usefulness (PU) as well as the perceived ease of use } \\
\text { (PEOU) would determine whether or not they would accept the } \\
\text { technology. TAM was later extended by Venkatesh and Davis } \\
\text { [47] to TAM2 to include subjective norms (SN) as an indicator of } \\
\text { the intent to use specifically in setting where use was } \\
\text { mandatory. } \\
\text { TAM2 was later extended into TAM3 by Venkatesh and Bala [53]. } \\
\text { In this extension the determinants of PU identified in TAM2 were } \\
\text { integrated with determinants of PEOU to form an integrated } \\
\text { model. The effect that moderating factors (experience and } \\
\text { Voluntariness) have on the determinants was also introduced. } \\
\text { TAM has been applied to a diverse set of users groups and } \\
\text { technologies. } \\
\text { TAM was developed for individual acceptance theory but has } \\
\text { been applied to organisational setting with success [19]. }\end{array}$ & $\begin{array}{ll}- & \text { Perceived usefulness } \\
\text { - } & \text { Perceived ease of } \\
\text { - } & \text { use } \\
\text { - } & \text { Subjective norms } \\
\text { Modention to use } \\
\text { - } \quad \text { Experience } \\
\text { - } \quad \text { Voluntariness }\end{array}$ \\
\hline $\begin{array}{l}\text { Innovation diffusion } \\
\text { theory } \\
\text { (IDT) }\end{array}$ & $\begin{array}{l}\text { Grounded in sociology, IDT has been used since the } 1960 \text { s to } \\
\text { study a variety of innovations. IDT sees innovations as being } \\
\text { transferred through certain channels over time and within a } \\
\text { particular cultures. The willingness of individuals to adopt a } \\
\text { technology generally exhibits a normal distribution that has } \\
\text { been broken into } 5 \text { categories. Innovators, early adopters, early } \\
\text { majority, late majority and laggards [15]. } \\
\text { Moore and Benbasat [31] adapted the innovation characteristics } \\
\text { for information systems to define a set of constructs that could } \\
\text { be used to study individual technology acceptance. } \\
\text { IDT has also been adapted to study firm level innovativeness. } \\
\text { The firm level of innovation is related to independent variables } \\
\text { that are associated with individual (leader) characteristics, } \\
\text { internal organisational structural characteristics, and external } \\
\text { characteristics of the organisation [20]. }\end{array}$ & 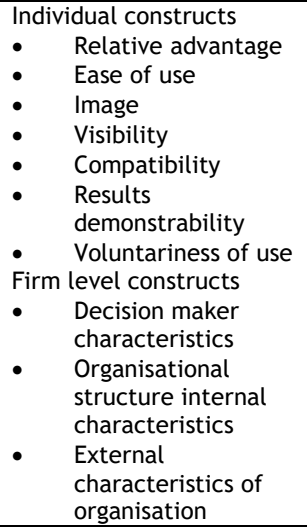 \\
\hline
\end{tabular}




\begin{tabular}{|c|c|c|}
\hline Acceptance Theory & Description and History & Core Constructs \\
\hline $\begin{array}{l}\text { Technology - } \\
\text { organisation - } \\
\text { environment model } \\
\text { (TOE) }\end{array}$ & $\begin{array}{l}\text { Introduced by Tornatzky and Fleischer [24], the TOE framework wa } \\
\text { to deal with aspects that influence the process adoption and imple } \\
\text { technological innovation in an organisational contexts. The three a } \\
\text { focusses on are: technological context, organisational context, and } \\
\text { TOE is consistent with IDT, in which Rogers emphasized } \\
\text { individual characteristics, and both the internal and external } \\
\text { characteristics of the organisation, as drivers for organisational } \\
\text { innovativeness. TOE however introduced the environment } \\
\text { context as a new component that has been found to impact } \\
\text { significantly on adoption behaviour. Various studies have proven } \\
\text { that TOE provides a useful analytical framework that can be } \\
\text { used for studying the adoption and assimilation of different } \\
\text { types of IT innovation [20]. }\end{array}$ & \begin{tabular}{ll}
\multicolumn{2}{l}{ Technology context } \\
- $\quad$ Availability \\
- $\quad$ Internal and external \\
characteristics \\
Environmental context \\
- $\quad$ Regulations \\
- $\quad$ Tech support \\
infrastructure \\
- $\quad$ Industry \\
$\quad$ characteristics and \\
market structure \\
Organisational context \\
- $\quad$ Linking structures \\
- $\quad$ Comm processes \\
$\quad$ Size
\end{tabular} \\
\hline $\begin{array}{l}\text { Unified theory of } \\
\text { acceptance and use of } \\
\text { technology } \\
\text { (UTAUT) }\end{array}$ & $\begin{array}{l}\text { Based on the most significant constructs from SCT, IDT, MPCU, } \\
\text { TPB, Motivation Model, TAM and TRA Venkatesh et al. [14] } \\
\text { formulated a new model called Unified Theory of Acceptance } \\
\text { and Use of Technology (UTAUT). UTAUT theorises performance } \\
\text { expectancy, effort expectancy, and social influence determine } \\
\text { behaviour intent for the adoption of information technology. As } \\
\text { with TAM, TPB and TRA, UTAUT expects behavioural intent to } \\
\text { influence use behaviour. They also predicted that facilitating } \\
\text { conditions as the fourth construct would influence use behaviour } \\
\text { but not behaviour intent. The model also includes moderating } \\
\text { factors for age, gender, experience and voluntariness that } \\
\text { explain the variation in the adoption across the various } \\
\text { constructs. }\end{array}$ & $\begin{array}{ll}\text { - } & \text { Performance } \\
\text { - } & \text { expectancy } \\
\text { - } & \text { Social influence } \\
\text { - } & \text { Facilitating } \\
& \text { conditions } \\
\text { - } \quad \text { Behaviour intent } \\
\text { Moderating factors: } \\
\text { - } \quad \text { Age } \\
\text { - } \quad \text { Gender } \\
\text { - } \quad \text { Voluntariness }\end{array}$ \\
\hline $\begin{array}{l}\text { Mobile enterprise } \\
\text { model (MEM) }\end{array}$ & $\begin{array}{l}\text { The MEM was introduce by Barnes [54] as a theoretical } \\
\text { framework for understanding mobile application at a } \\
\text { firm level, specifically concentrating on the business to } \\
\text { employee (B2E) channel. The framework is centred on } \\
\text { three dimensions, which all have distinct stages that } \\
\text { define the degree to which an organisations operational } \\
\text { needs (specifically relating to employee tasks) are } \\
\text { supported in a spatial and temporal independent way } \\
\text { [1]. Dim 1: Mobility, describes the level of spatial } \\
\text { independence" of enterprise workers. Dim 2: Process } \\
\text { describes the transformation operational processes } \\
\text { resulting from the adoption of a mobile application } \\
\text { technology. Dim 3: Market, refers to the alterations in } \\
\text { products services and relationships that describes the } \\
\text { value proposition. }\end{array}$ & \begin{tabular}{ll}
\multicolumn{2}{l}{ Mobility } \\
- & Transient \\
- & Mobile \\
- & Remote \\
Process \\
- $\quad$ Automation \\
- $\quad$ Information \\
- $\quad$ Transformation \\
Market \\
- $\quad$ Channel access \\
- $\quad$ Service value \\
- $\quad$ Service creation
\end{tabular} \\
\hline $\begin{array}{l}\text { Model of pc } \\
\text { utilization (MPCU) }\end{array}$ & $\begin{array}{l}\text { Thompson, Higgins and Howell [55] adapted the Triandis } \\
\text { (1977) theory of human behaviour to model acceptance } \\
\text { and usage of personal computers which became known } \\
\text { as the model of PC utilization. The Triandis theory } \\
\text { challenges the models proposed by TRA and TPB in the } \\
\text { sense that it makes a distinction between cognitive and } \\
\text { affective components of attitude. "Behaviour is } \\
\text { determined by what people would like to do (attitudes), } \\
\text { what they think they should do (social norms), what } \\
\text { they have usually done (habits), and by the expected } \\
\text { consequences of their behaviour" [55]. Although MPCU } \\
\text { was originally developed for PC utilization it has been } \\
\text { suggested that the model lends itself to predicting } \\
\text { individual acceptance and use of a range of information } \\
\text { technologies [51]. }\end{array}$ & $\begin{array}{ll}\text { - } & \text { Job fit } \\
\text { - } & \text { Complexity } \\
\text { - } & \text { Long term } \\
& \text { consequence } \\
\text { - } & \text { Affect towards use } \\
\text { - } & \text { Social factors } \\
\text { - } & \text { Facilitating } \\
& \text { conditions }\end{array}$ \\
\hline
\end{tabular}




\begin{tabular}{|c|c|c|}
\hline Acceptance Theory & Description and History & Core Constructs \\
\hline $\begin{array}{l}\text { Social cognitive } \\
\text { theory (SCT) }\end{array}$ & $\begin{array}{l}\text { SCT was introduced by Bandura [56] as an extension of } \\
\text { his early behaviour change model Social Learning } \\
\text { Theory. In this theory Bandura posited that within a } \\
\text { social context learning would occur when there is a } \\
\text { dynamic and reciprocal interaction of the person, } \\
\text { environment, and behaviour. Venkatesh et al. [14] } \\
\text { reports that Compeau and Higgins (1995) studied SCT in } \\
\text { the context of pc utilization and although this study } \\
\text { centred on usage, the nature of the model and the } \\
\text { underlying theory allow it to be extended to the } \\
\text { prediction of technology acceptance and use of } \\
\text { information technology in general. }\end{array}$ & $\begin{array}{ll}\text { - } & \text { Outcomes } \\
\text { expectations - } & \text { performance } \\
\text { - } & \text { Outcomes } \\
& \text { expectations - } \\
\text { personal } \\
\text { - } & \text { Self-efficacy } \\
\text { - } & \text { Affect } \\
\text { - } & \text { Anxiety }\end{array}$ \\
\hline $\begin{array}{l}\text { Task - technology fit } \\
\text { (TTF) }\end{array}$ & $\begin{array}{l}\text { Introduced by Goodhue and Thompson [28], TTF theory } \\
\text { posits that information technology is more likely to not } \\
\text { only impact individual performance positively but to } \\
\text { increase utilization if the capabilities of the technology } \\
\text { matches the tasks that the user is required to perform. } \\
\text { In this theory } 8 \text { distinct variables were introduced that } \\
\text { could be evaluated to determine the technology fit for a } \\
\text { task [57]. Zigurs and Buckland [58] presented a } \\
\text { comparable model that could be used to explain } \\
\text { information systems success at a group level. } \\
\text { Later Gebauer and Shaw [57] adapted the model for the } \\
\text { mobile information systems domain. They also reported } \\
\text { various studies that confirmed the relevance of the TTF } \\
\text { construct in assessing the value of an IS, to assess and } \\
\text { predict system usage, to explain individual } \\
\text { performance, to explain performance for both } \\
\text { mandatory and voluntary use settings. It was also found } \\
\text { to applicable to various technologies and for a variety of } \\
\text { tasks }\end{array}$ & $\begin{array}{ll}- & \text { Quality } \\
\text { - } & \text { Locatability } \\
\text { - } & \text { Authorization } \\
\text { - } & \text { Compatibility } \\
\text { - } & \text { Ease of } \\
& \text { use/training } \\
\text { - } & \text { Production } \\
\text { timeliness } \\
\text { - } & \text { Systems reliability } \\
\text { - } & \text { Relationship with } \\
& \text { users }\end{array}$ \\
\hline $\begin{array}{l}\text { Fit viability model } \\
\text { (FVM) }\end{array}$ & $\begin{array}{l}\text { Tjan [26] proposed the use of fit and viability as two } \\
\text { dimensions in evaluating internet initiatives. The } \\
\text { theoretical foundation for the fit dimension is the TTF } \\
\text { perspective that was introduced by Goodhue and } \\
\text { Thompson [28]. } \\
\text { In the FVM the fit construct is modified from TTF for a } \\
\text { more objective measure of the link between task and } \\
\text { technology with no consideration of individual abilities. } \\
\text { The viability construct refers to the extent to which the } \\
\text { organisation is ready for technology adoption taking } \\
\text { general economic feasibility, technical infrastructure } \\
\text { and the social readiness into consideration. FVM } \\
\text { theorises that performance will be impacted by fit and } \\
\text { viability and that applications with good task-technology } \\
\text { fit (TTF) and strong organisational viability are good } \\
\text { targets [27]. }\end{array}$ & $\begin{array}{ll}\text { Fit } & \\
\text { - } & \text { Task } \\
\text { - } & \text { Technology } \\
\text { - } & \text { Viability } \\
\text { - } & \text { Economic } \\
\text { - } & \text { IT infrastructure } \\
\text { - } & \text { Organisation }\end{array}$ \\
\hline
\end{tabular}




\begin{tabular}{|l|l|l|}
\hline Acceptance Theory & Description and History & Core Constructs \\
\hline Motivation model & $\begin{array}{l}\text { Motivation research was introduced as a theory to } \\
\text { explain behaviour. It suggest that behaviour is based on } \\
\text { extrinsic and intrinsic motivations. Extrinsic motivation } \\
\text { was defined by Davids and Warshaw (1992) as the } \\
\text { perception that users want to perform an activity } \\
\text { "because it is perceived to be instrumental in achieving } \\
\text { valued outcomes that are distinct from the activity } \\
\text { itself, such as improved job performance, pay, or } \\
\text { promotions". }\end{array}$ & $\begin{array}{l}\text { Intrinsic } \\
\text { motivation } \\
\text { Extrinsic } \\
\text { motivation }\end{array}$ \\
& $\begin{array}{l}\text { In the context of technology adoption models the } \\
\text { following construct could be defined as extrinsic } \\
\text { motivation factors: Perceived usefulness, perceived } \\
\text { ease of use, and subjective norms } \\
\text { Intrinsic motivation comes from the pleasure and } \\
\text { satisfaction derived from performing a task. } \\
\\
\\
\begin{array}{ll}\text { Li [51] reports findings from Davis and Warshaw [59] } \\
\text { that have linked elements of computer gamification to } \\
\text { intrinsic motivation. }\end{array}\end{array}$ & \\
\hline
\end{tabular}


Appendix 2 - The research instrument

\begin{tabular}{|c|c|c|c|c|}
\hline Area & Code & Description & Reference & Method \\
\hline \multirow{3}{*}{ General } & G1 & What is the size of your company & $\begin{array}{l}\text { Org } \\
\text { Character }\end{array}$ & Selection \\
\hline & G2 & Which industry does your company operate in & $\begin{array}{l}\text { Org } \\
\text { Character }\end{array}$ & Selection \\
\hline & $\mathrm{G} 3$ & In which country is your company located & Qualifier & Selection \\
\hline \multirow{4}{*}{ Demographic } & D1 & What is your current position & Position & Selection \\
\hline & D2 & What is you gender & Leader Char & Selection \\
\hline & D3 & What is your age group & Leader Char & Selection \\
\hline & D4 & What is your level of education & Leader Char & Selection \\
\hline \multirow{7}{*}{$\begin{array}{l}\text { Performance } \\
\text { Utility }\end{array}$} & PU1 & $\begin{array}{l}\text { MEA are useful to provide more timely and accurate information for } \\
\text { decision making }\end{array}$ & Useful & $\begin{array}{l}\text { Likert 1- } \\
7\end{array}$ \\
\hline & PU2 & $\begin{array}{l}\text { MEA are useful to provide an alternative mode of performing line of } \\
\text { business transactions }\end{array}$ & Useful & $\begin{array}{l}\text { Likert 1- } \\
7\end{array}$ \\
\hline & PU3 & MEA are useful to improve coordination between business units & Useful & $\begin{array}{l}\text { Likert 1- } \\
7\end{array}$ \\
\hline & PU4 & MEA are useful to increase competitive advantage & Useful & $\begin{array}{l}\text { Likert 1- } \\
7\end{array}$ \\
\hline & PU5 & MEA are useful to increase the speed of operations & Useful & $\begin{array}{l}\text { Likert 1- } \\
7\end{array}$ \\
\hline & PU6 & $\begin{array}{l}\text { MEA are is useful to expand market for existing products and } \\
\text { services }\end{array}$ & Useful & $\begin{array}{l}\text { Likert 1- } \\
7\end{array}$ \\
\hline & PU7 & MEA are useful to provide a mechanism to improve service delivery & Useful & $\begin{array}{l}\text { Likert 1- } \\
7\end{array}$ \\
\hline \multirow{4}{*}{$\begin{array}{l}\text { Technology } \\
\text { Usability }\end{array}$} & TU1 & MEA are easy to use and do not require much effort to learn & Easy & $\begin{array}{l}\text { Likert 1- } \\
7\end{array}$ \\
\hline & TU2 & MEA are implemented easily and efficiently & Risk & $\begin{array}{l}\text { Likert 1- } \\
7\end{array}$ \\
\hline & TU3 & MEA are compatible with existing technology in my company & Compatible & $\begin{array}{l}\text { Likert 1- } \\
7\end{array}$ \\
\hline & TU4 & $\begin{array}{l}\text { It is easy to use MEA to perform line of business transactions for my } \\
\text { company }\end{array}$ & Fits business & $\begin{array}{l}\text { Likert 1- } \\
7\end{array}$ \\
\hline \multirow{5}{*}{$\begin{array}{l}\text { External } \\
\text { Environment }\end{array}$} & EE1 & My company experiences competitive pressure to implement MEA & Competition & $\begin{array}{l}\text { Likert 1- } \\
7\end{array}$ \\
\hline & EE2 & $\begin{array}{l}\text { My company would experience a disadvantage if MEA is not } \\
\text { implemented }\end{array}$ & Competition & $\begin{array}{l}\text { Likert 1- } \\
7\end{array}$ \\
\hline & EE3 & Majority of leading companies in my industry use MEA & Ind trend & $\begin{array}{l}\text { Likert 1- } \\
7\end{array}$ \\
\hline & EE4 & $\begin{array}{l}\text { Majority of leading companies in my industry recognise that MEA can } \\
\text { enhance competitiveness }\end{array}$ & Inno paradox & $\begin{array}{l}\text { Likert 1- } \\
7\end{array}$ \\
\hline & EE5 & Technology advances for mobile devices support the use of MEA & Tech trend & $\begin{array}{l}\text { Likert 1- } \\
7\end{array}$ \\
\hline \multirow{16}{*}{$\begin{array}{l}\text { Enterprise } \\
\text { Readiness }\end{array}$} & ERTI1 & $\begin{array}{l}\text { My company has the infrastructure to secure MEA data over a } \\
\text { network }\end{array}$ & IT - security & $\begin{array}{l}\text { Likert 1- } \\
7\end{array}$ \\
\hline & ERTI2 & $\begin{array}{l}\text { My company has a wireless network infrastructure to support the use } \\
\text { of MEA }\end{array}$ & IT - network & $\begin{array}{l}\text { Likert 1- } \\
7\end{array}$ \\
\hline & ERTI3 & $\begin{array}{l}\text { My company has an information system infrastructure that is } \\
\text { compatible with MEA integration }\end{array}$ & IT - systems & $\begin{array}{l}\text { Likert 1- } \\
7\end{array}$ \\
\hline & ERTI4 & $\begin{array}{l}\text { My company has security policies in place that support the use of } \\
\text { mobile devices }\end{array}$ & IT - Policies & $\begin{array}{l}\text { Likert 1- } \\
7\end{array}$ \\
\hline & ERP1 & $\begin{array}{l}\text { Process changes caused by MEA adoption are easily integrated into } \\
\text { current business practices }\end{array}$ & Process & $\begin{array}{l}\text { Likert 1- } \\
7\end{array}$ \\
\hline & ERP2 & $\begin{array}{l}\text { My company has processes that require timeous data proliferation } \\
\text { for decision making }\end{array}$ & Process & $\begin{array}{l}\text { Likert 1- } \\
7\end{array}$ \\
\hline & ERS3 & $\begin{array}{l}\text { My company regularly introduces innovative solutions for processes } \\
\text { and products }\end{array}$ & Strategy & $\begin{array}{l}\text { Likert 1- } \\
7\end{array}$ \\
\hline & ERE1 & Employees in my company understand the benefit of MEA & Employee & $\begin{array}{l}\text { Likert 1- } \\
7\end{array}$ \\
\hline & ERE2 & $\begin{array}{l}\text { Employees in my company are familiar with mobile applications and } \\
\text { how they function }\end{array}$ & Employee & $\begin{array}{l}\text { Likert 1- } \\
7\end{array}$ \\
\hline & ERE3 & $\begin{array}{l}\text { My company experiences pressure from employees to implement } \\
\text { MEA }\end{array}$ & Employee & $\begin{array}{l}\text { Likert 1- } \\
7\end{array}$ \\
\hline & ERK1 & $\begin{array}{l}\text { The IS employees in my company have a good understanding of MEA } \\
\text { support requirements }\end{array}$ & Knowledge & $\begin{array}{l}\text { Likert 1- } \\
7\end{array}$ \\
\hline & ERK2 & $\begin{array}{l}\text { My company hires people who are specialised or knowledgeable on } \\
\text { MEA }\end{array}$ & Knowledge & $\begin{array}{l}\text { Likert 1- } \\
7\end{array}$ \\
\hline & ERR1 & $\begin{array}{l}\text { My company ensures that there are sufficient financial resources } \\
\text { available to implement MEA }\end{array}$ & $\begin{array}{l}\text { Resource - } \\
\text { fin }\end{array}$ & $\begin{array}{l}\text { Likert 1- } \\
7\end{array}$ \\
\hline & ERR2 & $\begin{array}{l}\text { My company ensures that there are sufficient technical resources } \\
\text { available to implement MEA }\end{array}$ & Resource - IT & $\begin{array}{l}\text { Likert 1- } \\
7\end{array}$ \\
\hline & ERR3 & $\begin{array}{l}\text { My company ensures that there are sufficient human resources } \\
\text { available to implement MEA }\end{array}$ & $\begin{array}{l}\text { Resource - } \\
\text { HR }\end{array}$ & $\begin{array}{l}\text { Likert 1- } \\
7\end{array}$ \\
\hline & ERL1 & Senior management has a good understanding of MEA technology & Leader ready & $\begin{array}{l}\text { Likert 1- } \\
7\end{array}$ \\
\hline
\end{tabular}




\begin{tabular}{|l|l|l|l|l|}
\hline \multicolumn{1}{|c|}{ Area } & Code & \multicolumn{1}{|c|}{ Description } & Reference & \multicolumn{1}{c|}{ Method } \\
\hline & ERL2 & Senior management understands the benefits that MEA can offer & Leader ready & $\begin{array}{l}\text { Likert 1- } \\
7\end{array}$ \\
\hline Organisation & OCS & Refer to size of organisation question - G1 & Size & Selection \\
\hline \multirow{4}{*}{$\begin{array}{l}\text { Leadership } \\
\text { Character }\end{array}$} & LC1 & What is the average age of senior management in your company & Leader - age & Selection \\
\cline { 2 - 5 } & LC2 & $\begin{array}{l}\text { What is the predominant gender makeup of the senior managers in } \\
\text { your company }\end{array}$ & Leader - gen & Selection \\
\cline { 2 - 6 } & LC3 & $\begin{array}{l}\text { What is the predominant level of education of the senior managers } \\
\text { in your organisation }\end{array}$ & Leader - edu & Selection \\
\hline Voluntary & V1 & $\begin{array}{l}\text { When information systems technology is adopted by my company the } \\
\text { use thereof is voluntary }\end{array}$ & Setting & Likert \\
\hline Usage Intent & UI1 & Does your company intend on implementing MEA in the near future & Intent & Yes / No \\
\hline Actual Usage & AU1 & Has your company adopted any MEA technology & Intent & Yes / No \\
\hline
\end{tabular}

